\title{
Cytotoxicity and the bioconversion strategy of Aristolochia spp.
}

\author{
Cláudio Rodrigo Nogueira',* (1) https://orcid.org/0000-0003-2267-4754 \\ José Darlan Alves da Silva² (1) https://orcid.org/0000-0002-1700-8645 \\ Maria do Carmo Vieira ${ }^{3}$ (D) https://orcid.org/0000-0001-7047-3848 \\ Claudia Andrea Lima Cardoso² (1) https://orcid.org/0000-0002-4907-0056 \\ Renata Aquino de Carvalho 4 (1) https://orcid.org/0000-0002-5758-4073 \\ Creusa Sayuri Tahara Amaral ${ }^{4}$ (10) https://orcid.org/0000-0003-4959-2636 \\ André Capaldo Amaral ${ }^{4}$ (1) https://orcid.org/0000-0001-9625-1442
}

\begin{abstract}
1. Universidade Federal da Grande Dourados - Faculdade de Ciências Exatas e Tecnologia - Dourados (MS), Brazil.
2.Universidade Estadual de Mato Grosso do Sul - Programa de Pós-Graduação em Recursos Naturais - Dourados (MS), Brazil.

3.Universidade Federal da Grande Dourados - Faculdade de Ciências Agrárias - Dourados (MS), Brazil.

4.Universidade de Araraquara - Programa de Pós-Graduação em Biotecnologia em Medicina Regenerativa e Química Medicinal Araraquara (SP), Brazil.

${ }^{\star}$ Corresponding author: claudiornogueira@ufgd.edu.br
\end{abstract}

\begin{abstract}
Aristolochia plants are notable from an ethnopharmacological viewpoint, but the relevance of these species for medicinal purposes has been debated because of their inherent toxicity. The convergence of these contrasting realities can be readily achieved using bioconversion methods, which have been shown to be useful tools for numerous applications, including the detoxification of biomass. In this context, methanolic extracts of leaves from Aristolochia triangularis and Aristolochia gibertii, as well as the feces of Battus polydamas larvae fed with leaves from these plants, were prepared, and their cytotoxic activities were evaluated on a human fibroblast cell line (GMO7492). The leaf extracts were found to be cytotoxic, leading to reductions of 42.1 and $33.8 \%$ on cell viability, respectively, while the fecal extracts were considered inactive. In addition to evidencing the cytotoxicity of A. triangularis and A. gibertii, these findings demonstrated a potential bioconversion strategy for obtaining aristolochiaceous extracts with reduced toxicity using the larvae of a specialist phytophagous insect, thus renewing expectations in relation to the pharmacological importance of Aristolochia spp. The results were also ecologically relevant, as B. polydamas larvae were found to be able to detoxify compounds from host plants.
\end{abstract}

Keywords: Aristolochiaceae; bioconversion; insects; toxicity; detoxification.

\section{INTRODUCTION}

Despite being time-consuming, the natural product chemistry approaches continue to be the most promising for the discovery of new drugs. This statement remains valid even when the efficiencies of these strategies are compared with those of advanced tools, such as combinatorial chemistry and high-throughput screening of synthesized compounds (CHAGAS-PAULA et al., 2015).

However, the initial selection of a bioactive extract with minimal to no toxicity is a bottleneck to success in drug discovery programs (MCGAWL et al., 2014). Hence, extract libraries are usually initially submitted to toxicity testing, for example cytotoxicity assays, which are also used for other purposes, such as the search for anticancer drugs and the samples found to be toxic are classified as nonpriority (MCGAWL et al., 2014). Although the merit of this approach is widely recognized, caution should be exercised when applying it for three related reasons: i) it is essentially reductionist, ii) extracts are highly complex matrices and their potential should not be underestimated based on toxicological screening results, and iii) even biomasses/samples that are inherently toxic and/or inactive may show promise after being processed or engineered using tools such as bioconversion methods and strategies to generate natural product-like libraries (LÓPEZ et al., 2007; LIU; YU, 2010).

Received: Jul 07, 2019 Accepted: Nov 24, 2020

Associate Editor: Silvia Galleti

Peer Review History: Double-blind Peer Review. 
The Aristolochiaceae family is an example of why caution should be observed before drawing an immediate conclusion regarding the pharmacological significance of certain plants. Species of this family of flowering plants, particularly those of the Aristolochia genus, contain a great number of bioactive compounds, making them notable within the global ethnopharmacological context (LOPES et al., 2001; HEINRICH et al., 2009). However, their medicinal potential conflicts with results of several toxicological studies, which demonstrated the cytotoxicity and mutagenicity of its representative chemical constituents as well as of herbal preparations containing such plants (LOPES et al., 2001; DECHBUMROONG et al., 2018; HAN et al., 2019). These findings have stimulated debate regarding the relevancy of Aristolochia spp. for medicinal purposes and have encouraged the development of approaches to overcome this issue (NOGUEIRA; LOPES, 2013a,b; DECHBUMROONG et al., 2018).

Among the various methods, bioconversion, which strictly differs from biotransformation and involves the use of living organisms (COLLINS; KENNEDY, 1999), has attracted great interest, as it has proven to be a very useful tool for numerous applications, including access to new compounds, structural modification and biomass detoxification (PALMQVIST et al., 2000; LIU; YU, 2010; NOGUEIRA; LOPES, 2013a,b). The greatest attention has been given to the utilization of microorganisms for these purposes, but the potential of insects, including the Swallowtail butterfly Battus polydamas, has also been verified (VENISETTY; CIDDI, 2003; NOGUEIRA; LOPES, 2013a,b; RAMOS, 2013).

Thus, the objective of this work was to evaluate the in vitro cytotoxicity of Aristolochia triangularis and Aristolochia gibertii before and after metabolization of leaf biomasses of these species by larvae of a specialist phytophagous insect, B. polydamas, in order to propose a potential bioconversion approach to obtain aristolochiaceous extracts with reduced toxicity, contributing to overcome challenges that have limited the use of the birthwort family for therapeutic purposes.

\section{MATERIAL AND METHODS}

\section{Plant materials and insects: collection and identification}

The plant materials and insects were collected at the Medicinal Plants Garden of the Federal University of Grande Dourados, Dourados (MS), Brazil, during April 2016. A. triangularis Cham. and A. gibertii Hook. were identified by Dr. Joelcio Freitas and voucher specimens (MBML 53232 and MBML 53233, respectively) were deposited at the herbarium of Museu de Biologia Prof. Mello Leitão (MBML) in city of Santa Teresa, Espírito Santo, Brazil. Battus polydamas was identified by MSc. Paulo Ricardo Barbosa de Souza. The authorization IBAMA number was 51842 and the access registers CGEN/MMA numbers were AC96E87 and A1F6637.

\section{Larval rearing and collection of fecal material}

Battus polydamas larvae of different instars, which were fed in the laboratory with fresh leaves from A. triangularis or A. gibertii during the first half of April 2016, were reared in cages $[30 \times 30 \times 40 \mathrm{~cm}(\mathrm{w} \times \mathrm{h} \times 1)]$ under semicontrolled conditions: artificial light during the natural photoperiod and ambient humidity and temperature. The fecal materials excreted by the insects were collected every $48 \mathrm{~h}$, air-dried for 15 days and stored at room temperature until extraction.

\section{Extraction steps}

The feces of the B. polydamas larvae fed with A. triangularis and A. gibertii leaves (60.0 $\mathrm{g}$ and $8.6 \mathrm{~g}$, respectively) and leaves from these two plants (25.6 and 10.0, respectively) were individually and exhaustively extracted by maceration with methanol (HPLC grade, Vetec). After the simple filtration steps, the obtained methanol solutions were concentrated under reduced pressure to give the extracts of the feces [FE-1: $6.82 \mathrm{~g}(11.4 \%)$; FE-2: $0.92 \mathrm{~g}(10.7 \%)$ ] and leaves [LE-1: $4.92 \mathrm{~g}(19.2 \%) ; \mathrm{LE}-2: 1.28 \mathrm{~g}(12.8 \%)$ ].

\section{Cytotoxic activity and data analysis}

The cytotoxicity of the methanol extracts of B. polydamas feces and A. triangularis and A. gibertii leaves were evaluated using the liquid extraction method (International Standard ISO 10993-5, 2009). GM07492 cells were seeded in a 96-well plate, maintained in culture medium enriched with fetal bovine serum (FBS) and antibiotics, and incubated for $24 \mathrm{~h}$ at $37^{\circ} \mathrm{C}$ in a humidified atmosphere containing $\mathrm{CO}_{2}(5 \%)$ and atmospheric air (95\%). The extract samples were individually prepared at a concentration of $20 \mathrm{mg} / \mathrm{mL}$ using Dulbecco's modified eagle medium (DMEM) as a diluent and allowed to stand for $24 \mathrm{~h}$ at $37^{\circ} \mathrm{C}$. After 
this time, the culture medium of the wells was replaced with $100 \mu \mathrm{L}$ of culture medium containing either the extracts, the negative control or the positive control, or vehicle, and the cells were maintained under ideal cultivation conditions for $24 \mathrm{~h}$. Subsequently, the wells were washed with $150 \mu \mathrm{L}$ phosphate buffered saline (PBS) (1×) and $50 \mu \mathrm{L}$ of 3-(4,5-dimethylthiazol-2-yl)-2,5-diphenyltetrazolium bromide (MTT) was added to each. The 96 -well plate was again incubated for $4 \mathrm{~h}$ at $37^{\circ} \mathrm{C}$, after which $100 \mu \mathrm{L}$ of isopropanol was added to each well to solubilize the formazan crystals. Finally, the quantity of dissolved formazan crystals was determined spectrophotometrically and the optical density values measured at $570 \mathrm{~nm}$ were converted into the perceptual of cell viability in relation to a negative control. DMEM + FBS + antibiotics and DMEM + DMSO 25\% were used as the negative and positive controls, respectively. The calculations of the reduction in cell viability were performed following the recommendations described in International Standard ISO 10993-5 (2009).

\section{RESULTS AND DISCUSSION}

Monolayers of GM 07492 cells were individually treated with $100 \mu \mathrm{L}$ of culture medium containing $2 \mathrm{mg}$ of one of the extracts to be tested: LE-1, FE-1, LE-2, or FE-2. Relative cell viability values of $57.9,85.8,66.2$ and $94.2 \%$ were obtained for the samples, respectively (Fig. 1), corresponding to $42.1,14.2,33.8$, and $5.8 \%$ reductions in the cell viability as determined using liquid extraction assay.

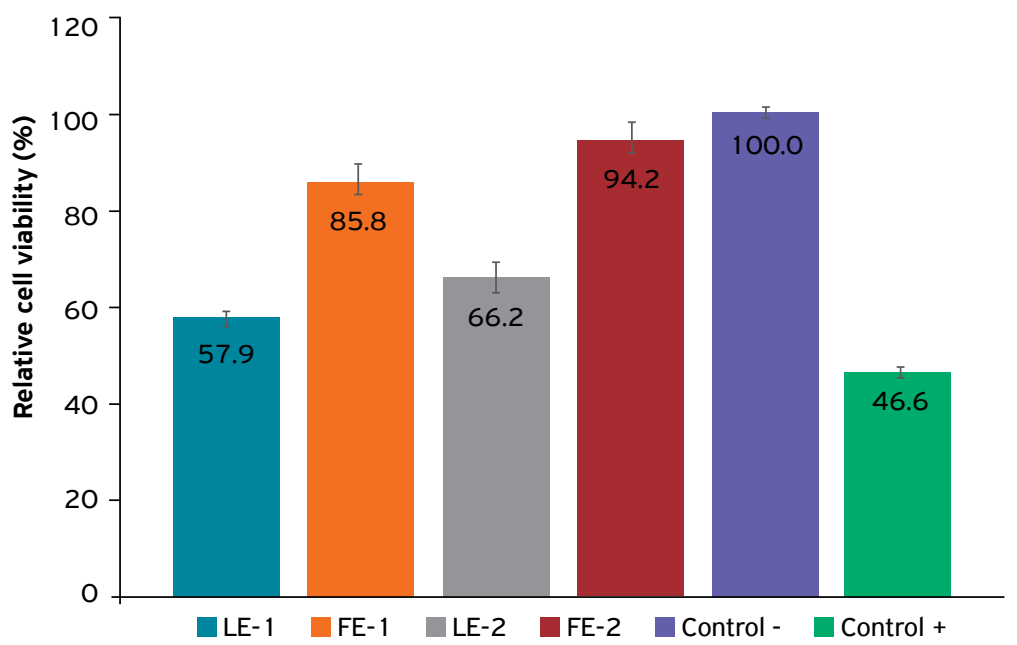

Figure 1. Relative cell viability values. The graph shows the comparison of cell viability between extracts of leaves and feces in relation to the negative and positive controls. LE- 1 and LE-2: extracts of leaves from $A$. triangularis and $A$. gibertii, respectively. FE- 1 and FE-2: extracts of feces of $B$. polydamas larvae fed on $A$. triangularis and $A$. gibertii leaves, respectively.

A reduction of more than $30 \%$ in cell viability can be interpreted as a cytotoxic effect (International Standard ISO 10993-5, 2009). Therefore, the LE-1 and LE-2 extracts were cytotoxic at the concentration assessed, with the former presenting significantly greater toxic action than the later $(\mathrm{p} \leq 0.00)$. In previous studies, extracts from $A$. triangularis were shown to cause mortality in Artemia salina larvae, as well as being cytotoxic in an Allium cepa bioassay and towards KB cells (MONGELLI et al., 1996; 2000; SILVA et al., 2019). Conversely, the toxicological properties of $A$. gibertii had not been previously described in literature.

The cytotoxicity of LE-1 and LE-2 reflected their chemical compositions, since both plants selected for this work can produce compounds that are known to be cytotoxic. Nearly fifty compounds have been reported to occur in A. triangularis, among which only aristolactam I and aristolochic acids I, II, C and D, all of which are cytotoxic, were detected in leaves of this species (SILVA et al., 2019; MICHL et al., 2016). In contrast, a total of twelve chemical constituents, including the cytotoxic lignans cubebin, (-)-hinokinin, and (-)-kusunokinin, have been isolated from A. gibertii leaves (MARCHESINI et al., 2009).

As expected, the fecal extracts were not considered cytotoxic, which supported the hypothesis of this study that bioconversion by B. polydamas larvae would be an efficient way to obtain Aristolochiaceous extracts with minimal to no toxicity. Consequently, the method developed in this research could renew expectations regarding the potential of the controversial Aristolochia spp.

These results also had chemical-ecological relevancy, since they suggest that B. polydamas larvae detoxify the chemical constituents of their host plants. Phytophagous insects have developed a variety of strategies to overcome the chemical barriers imposed by plants (EDWARDS; WRATTEN, 1981; OPTIZ; MÜLLER, 2009; RAMOS, 2013). A particularly effective way of dealing with this issue is to metabolize the chemical constituents via a variety of metabolic pathways or with the help of 
endosymbiotic microorganisms (EDWARDS; WRATTEN, 1981; OPTIZ; MÜLLER, 2009; RAMOS, 2013). Similar detoxification pathways have been observed in Lepidoptera, whose larvae feed on plants belonging to several botanical families (RAMOS, 2013). The toxic compounds in the plants are generally transformed into more polar and less toxic derivatives, mainly by demethylation, hydroxylation and glycosylation reactions (RAMOS, 2013).

Although virtually nothing is known about the toxicity of most bioconversion products, $B$. polydamas larvae are known to be able to metabolize aristolochic acids (AAs), aristolactams (ALs), lignans and diterpenes (NOGUEIRA; LOPES, 2013a,b; NOGUEIRA, 2014). For the metabolism of AAs, all chemical transformations mentioned above have already been observed, although the glycosylated derivatives still lack an unambiguous structural determination (PRIESTAP et al., 2012). A single study on the metabolism of ALs has been published in the literature, which verified that the ALs I and II were oxidized into AAs I and II, respectively (URZÚA et al., 2013). The metabolism of dibenzylbutyrolactone lignans by B. polydamas larvae produced (-)-( $\left.8 S, 8 R^{\prime}\right)$ (3,4-methylenedioxy)-(3',4')-(dimethoxy)-9'-O- $\beta$-glucopyranosyl-lignan-9-oic acid and (-)-(8S,8R')-[3,4:3',4'-bis(methylenedioxy)]9'-O- $\beta$-glucopyranosyl-lignan-9-oic acid, whereas the labdane diterpene (-)-(5R,8R,9S,10R,13R)-8-hydroxy-labdan-15-oic acid was bioconverted into (4S,5S,8R,9S,10R,13R)-8,18-dihydroxy-labdan-15-oic acid, (4S,5S,7R,8S,9S,10R,13R)-7,8,18-trihydroxy-labdan-15-oic acid and (-)-(4S,5S,8R,9S,10R,13R)-8-hydroxy-labdan-15,18-dioic acid (NOGUEIRA; LOPES, 2013a,b; NOGUEIRA, 2014).

\section{CONCLUSIONS}

Extracts of A. triangularis and A. gibertii leaves were found to be cytotoxic to GM07492 cells, whereas the extracts of the feces of $B$. polydamas larvae fed on leaves of these plants were inactive. Thus, the bioconversion strategy utilized in this work was shown to be effective for the detoxification of aristolochiaceous foliar biomasses, renewing expectations of the pharmacological relevance of Aristolochia spp. The reduction in toxicity observed after the digestion of leaves from these two plants by $B$. polydamas larvae also had chemical-ecological implications, as it demonstrated that these insects may have their own strategies to overcome the chemical barriers imposed by their host plants.

\section{AUTHORS' CONTRIBUTIONS}

Conceptualization: Nogueira, C.R.; Silva, J.D.A.; Vieira, M.C.; Cardoso, C.A.L.; Amaral, A.C. Data curation: Nogueira, C.R.; Silva, J.D.A.; Carvalho, R.A.; Amaral, C.S.T., Amaral, A.C. Formal analysis: Nogueira, C.R.; Silva, J.D.A.; Carvalho, R.A. Funding acquisition: Nogueira, C.R.; Vieira, M.C.; Cardoso, C.A.L.; Amaral, C.S.T.; Amaral, A.C. Methodology: Nogueira, C.R.; Silva, J.D.A; Vieira, M.C.; Cardoso, C.A.L.; Carvalho, R.A.; Amaral, C.S.T.; Amaral, A.C. Writing - review \& editing: all author contributed equally.

\section{AVAILABILITY OF DATA AND MATERIAL}

All data generated or analyzed during this study are included in this published article.

\section{FUNDING}

Coordenação de Aperfeiçoamento de Pessoal de Nível Superior

http://doi.org/10.13039/501100002322

Finance Code: 001

Conselho Nacional de Desenvolvimento Científico e Tecnológico

http://doi.org/10.13039/501100003593

Grant No: 404944/2016-7 and 311975/2018-6

Fundação de Apoio ao Desenvolvimento do Ensino, Ciência e Tecnologia do Estado de Mato Grosso do Sul

http://doi.org/10.13039/501100005672

Grant No: 59/300.029/2015; 71/700.139/2018; 036/20108; and SIAFEM 028991

\section{CONFLICTS OF INTEREST}

The authors certify that they have no commercial or associative interest that represents a conflict of interest in connection with the manuscript.

\section{ETHICAL APPROVAL}

Not applicable.

\section{ACKNOWLEDGEMENTS}

The authors would like to thank Dr. Joelcio Freitas and MSc. Paulo Ricardo Barbosa de Souza for botanical and entomological identifications. 


\section{REFERENCES}

CHAGAS-PAULA, D.A.; ZHANG, T.; COSTA, F.B.; EDRADA-EBEL, R. A Metabolomic approach to target compounds from the Asteraceae family for dual COX and LOX inhibition. Metabolites, Basel, v.5, n.3, p.404-430, 2015. https://doi.org/10.3390/metabo5030404

COLLINS, A.M.; KENNEDY, M.J. Biotransformations and bioconversions in New Zealand: Past Endeavours and Future Potential. Australasian Biotechnology, Botafogo, v.9, n.2, p.86-94, 1999. Available from: http://www.bioline.org.br/request?au99006. Access on: 15 Apr. 2019.

DECHBUMROONG, P.; AUMNOUYPOL, S.; DENDUANGBORIPANT, J.; SUKRONG, S. DNA barcoding of Aristolochia plants and development of species-specific multiplex PCR to aid HPTLC in ascertainment of Aristolochia herbal materials. PLoS ONE, San Francisco, v.13, n.8, e0202625, p.1-16, 2018. https://doi.org/10.1371/journal.pone.0202625

EDWARDS, P.J.; WRATTEN, S.D. Ecologia das interações entre insetos e plantas. São Paulo: Pedagógica e Universitária, 1981, 71p.

HEINRICH, M.; CHAN, J.; WANKE, S.; NEINHUIS, C.; SIMMONDS, M.S.J. Local uses of Aristolochia species and content of nephrotoxic aristolochic acid 1 and 2-A global assessment based on bibliographic sources. Journal of Ethnopharmacology, v.125, n.1, p.108-144, 2009. https://doi.org/10.1016/j.jep.2009.05.028

HAN, J.; XIAN, Z.; ZHANG, Y.; LIU, J.; LIANG, A. Systematic overview of aristolochic acids: nephrotoxicity, carcinogenicity, and underlying mechanisms. Frontiers in Pharmacology, v.10, p. 1-17, 2019. https://doi.org/10.3389/fphar.2019.00648

[ISO] International Organization for Standardization. 10993-5: 2009 Biological evaluation of medical devices-Part 5: Tests for in vitro cytotoxicity. Geneva: ISO, 2009. Available from: https://www.iso.org/standard/36406.html. Access on: 5 Aug. 2017.

LIU, J.-H.; YU, B.-Y. Biotransformation of bioactive natural products for pharmaceutical lead compounds. Current Organic Chemistry, Budapest, v.14, n.14, p.1400-1406, 2010. https://doi.org/10.2174/138527210791616786

LOPES, L.M.X.; NASCIMENTO, I.R.; SILVA, T.D.; DA, L.M. Phytochemistry of the Aristolochiaceae Family. In: MOHAN, R.M.M. (ed). Research Advances in Phytochemistry. Kerala: Global Research Network, 2001, p.19-108.

LÓPEZ, S.N.; RAMALLO, I.A.; SIERRA, M.G.; ZACCHINO, S.A.; FURLAN, R.L.E. Chemically engineered extracts as an alternative source of bioactive natural product-like compounds. Proceedings of the National Academy of Sciences of the United States of America, Washington, v.104, n.2, p.441-444, 2007. https://doi.org/10.1073/pnas.0608438104

MARCHESINI, A.M.; PRADO, G.G.; MESSIANO, G.B.; MACHADO, M.B.; LOPES, L.M.X. Chemical constituents of Aristolochia giberti. Journal of the Brazilian Chemical Society, São Paulo, v.20, n.9, p.1598-1608, 2009. https://doi.org/10.1590/S0103-50532009000900006

MCGAWL, L.J.; ELGORASHI, E.E.; ELOFF, J.N. Cytotoxicity of African medicinal plants against normal animal and human cells. In: KUETE, V. (ed). Toxicological Survey of African Medicinal Plants. London: Elsevier, 2014. chap.8, p.181-233. https://doi.org/10.1016/ B978-0-12-800018-2.00008-X

MICHL, J.; KITE, G.C.; WANKE, S.; ZIERAU, O.; VOLLMER, G.; NEINHUIS, C.; SIMMONDS, M.S.J.; HEINRICH, M. LC-MS- and ${ }^{1} H$ NMR-based metabolomic analysis and in vitro toxicological assessment of 43 Aristolochia species. Journal of Natural Products, Washington, v.79, n.1, p.30-37, 2016. https://doi.org/10.1021/acs.jnatprod.5b00556

MONGELLI, E.; MARTINO, V.; COUSSIO, J.; CICCIA, G. Screening of Argentine medicinal plants using the brine shrimp microwell cytotoxicity assay. International Journal of Pharmacognosy, Springfield, v.34, n.4, p.249-254, 1996. https://doi.org/10.1076/phbi.34.4.249.13234

MONGELLI, E.; PAMPURO, S.; COUSSIO, J.; SALOMON, H.; CICCIA, G.J. Cytotoxic and DNA interaction activities of extracts from medicinal plants used in Argentina. Journal of Ethnopharmacology, Pretoria, v.71, n.1-2, p.145-151, 2000. https://doi.org/10.1016/ S0378-8741(99)00195-6

NOGUEIRA, C.R. Biotransformação e sequestro de micromoléculas de Aristolochia gibertii por Battus polydamas. 288f. Thesis (Doctorate in Chemistry) - Universidade Estadual Paulista, Araraquara, 2014. Available from: https://repositorio.unesp.br/handle/11449/115794. Access on: 15 Apr. 2019. 
NOGUEIRA, C.R.; LOPES, L.M. Determination of configuration at C-13 of (-)-ent-8 $\beta$-hydroxy-labdan-15-oic acid and its biotransformation by Battus polydamas larvae. Planta Medica, New York, v.79, SL35, 2013a. https://doi.org/10.1055/s-0033-1351861

NOGUEIRA, C.R.; LOPES, L.M. Sequestration and biotransformation of lignans from Aristolochia giberti by Battus polydamas larvae (Papilonidae: Troidini). Planta Medica, New York, v.79, PI67, 2013b. https://doi.org/10.1055/s-0033-1352156

OPTIZ, S.E.W.; MÜLLER, C. Plant chemistry and insect sequestration. Chemoecology, Graz, v.19, n.3, p.117-154, 2009. https://doi. org/10.1007/s00049-009-0018-6

PALMQVIST, E.; HAHN-HÄGERDAL, B. Fermentation of lignocellulosic hydrolysates. I: inhibition and detoxification. Bioresource Technology, Lucknow, v.74, n.1, p.17-24, 2000. https://doi.org/10.1016/S0960-8524(99)00160-1

PRIESTAP, H.A.; VELANDIA, A.E.; JOHNSON, J.V.; BARBIERI, M.A. Secondary metabolite uptake by the Aristolochia-feeding papilionoid butterfly Battus polydamas. Biochemical Systematics and Ecology, Richmond, v.40, p.126-137, 2012. https://doi.org/10.1016/j.bse.2011.10.006

RAMOS, C.S. Biotransformation of secondary plant metabolites by Lepidoptera. In: GUERRITORE, E.; DESARE, J. (eds). Lepidoptera: classification, behavior, and ecology. New York: Nova Medical, 2013, chap.8, p.203-216.

SILVA, J.D.A.; NOGUEIRA, C.R.; VIEIRA, M.C.: HEREDIA-VIEIRA, S.C.; BARUFATTI, A.; CRISPIM, B.A.; FRANCISCO, L.F.V.; VIANA, L.F.; CARDOSO, C.A.L. Toxicological properties of an aqueous extract of Aristolochia triangularis leaves, using the brine shrimp lethality and Allium cepa bioassays. Ciência Rural, Santa Maria, v.49, n.8, p.e20190091, 2019. https://doi.org/10.1590/0103-8478cr20190091

URZÚA, A.; OLGUÍN, A.; SANTANDER, R. Fate of ingested aristolactams from Aristolochia chilensis in Battus polydamas archidamas (Lepidoptera: Papilionidae). Insects, Basel, v.4, n.4, p.533-541, 2013. https://doi.org/10.3390/insects4040533

VENISETTY, R.K.; CIDDI, V. Application of microbial biotransformation for the new drug discovery using natural drugs as substrates. Current Pharmaceutical Biotechnology, Athens, v.4, n.3, p.153-167, 2003. https://doi.org/10.2174/1389201033489847 